\title{
Effect of Hhydrogen Peroxide Foliar Spraying on Tuber's Quality of Three Potato Cultivars
}

\author{
Eslam Yaseen ${ }^{1}$; Mona M.Yousry ${ }^{1}$; Sameh A.M. Moussa ${ }^{2}$ and Ahmad M.A.EI- \\ Gamal $^{1}$
}

${ }^{1}$ Plant Production Dept.,Faculty of Agriculture, Saba-Basha, Alexandria University

${ }^{2}$ Sabaheya Horticultural Research Station, Horticultural Research Institute, Agriculture

Research Center, Egypt

\begin{abstract}
Two field experiments concerning potato (Solanum tuberosum L.) crop were carried out during two successive winter seasons of 2009/2010 and 2010/2011 in a private farm at a newly reclaimed area, in El-Amria region, Alexandria governorate, Egypt. The experiment was performed to study the effect of hydrogen peroxide $\left(\mathrm{H}_{2} \mathrm{O}_{2}\right)$ on the potato processing quality and the economical characters. The split-plot design in three replicates was used, where potato cultivars were placed in the main plots, while doses of foliar spraying with hydrogen peroxide were occupied the sub-plots. Three potato cultivars were tested in this investigation; Lady Rossetta, Valor and Mondial. Four doses of hydrogen peroxide were used as zero, 25, 50 and $75 \mathrm{mM}$ in the first year. Two higher doses, 100 and $125 \mathrm{mM}$ of hydrogen peroxide were added in the second year. Potato plant stem diameter was positively affected with the increasing of $\mathrm{H}_{2} \mathrm{O}_{2}$ concentrations from zero up to $125 \mathrm{mM}$. The results showed that the 25,50 and $75 \mathrm{mM}$ of $\mathrm{H}_{2} \mathrm{O}_{2}$ concentrations did not affect the potato tuber yield. The other two high levels $(100$ and $125 \mathrm{mM})$ of $\mathrm{H}_{2} \mathrm{O}_{2}$ resulted in lower potato yields. The number of tubers/ $10 \mathrm{Kg}$ weight trait seemed to be affected with $\mathrm{H}_{2} \mathrm{O}_{2}$ concentrations, in which it was above the accepted number during the second year (more than 112 tubers $/ 10 \mathrm{Kg}$ weight). In the first year, the data indicated that spraying potato plants with 75 or $50 \mathrm{mM}$ of $\mathrm{H}_{2} \mathrm{O}_{2}$ significantly increased dry matter percentage compared with the control treatment. Both treatments of 75 and $50 \mathrm{mM}$ of $\mathrm{H}_{2} \mathrm{O}_{2}$, produced the highest levels of tuber starch content in the first year, while the treatment $75 \mathrm{mM}$ of $\mathrm{H}_{2} \mathrm{O}_{2}$, produced the highly tuber starch content with significant differences among the other tested treatment in the second year of the study. The effect of hydrogen peroxide on parenchyma cell diameter trait differed from year to another. The treatment of $50 \mathrm{mM}$ of $\mathrm{H}_{2} \mathrm{O}_{2}$ possessed the highest value for parenchyma cell diameter trait, whereas, the treatments of both 25 and $125 \mathrm{mM}$ of $\mathrm{H}_{2} \mathrm{O}_{2}$ increased the parenchyma cell diameter trait. The lowest chipping defects were produced when potato plants sprayed with $50 \mathrm{mM} \mathrm{H}_{2} \mathrm{O}_{2}$. The control treatment gave the lowest mean value (result) where this treatment produced highly significant level of tuber chipping defects.
\end{abstract}

Key words: potato, Solanum tuberosum L., hydrogen peroxide, parenchyma cells, starch accumulation, total sugars, Dry matter percentage and chips defects.

\section{INTRODUCTION}

Potato (Solanum tuberosum L.) is the world number one of non-grain food commodity. The global production of potatoes is $324,181,889$ tons grown under an area reached about 18,596,233 hectares, and the world seed production was $31,567,656$ tons (FAO, 2010). Potato has an important position among all vegetable crops in Egypt, where about $20 \%$ of total area devoted for vegetable production, was cultivated with it. In addition, the total cultivation of potato, according to estimates of the Egyptian Ministry of Agriculture for the 
year 2012,reached 200 thousands feddans spread over three lugs (summer, Nili and winter) with a total production reached more than 2 million tons, with an average productivity about 10 tons per feddan (FAO, 2010).

In the past ten years, processing potatoes was increased in Egypt, both for the production of potato chips or for French fries. These processes require a number of specifications to keep the products in high quality. Among the most important factors is the high net product ratio which is highly associated with the percentage of dry matter and starch content, in addition to the lack of reducing sugars. Many researches were directed to increase the quality processing. Tuber starch is an important quality character for potato crops. Dry matter is, generally, used as an index of starch content by growers and breeders and it is an important factor to decide the destination of the produce (Gould and Plimpton, 1985; Estrada, 2000). Tubers with high dry matter content, for example, require less energy and absorb less oil during frying, and have a drier texture after cooking (Storey and Davies, 1992). Also; the acceptability of potatoes for processing is largely dependent on the color of the end product. Color is directly related to the quantity of sugars in the tuber. The quantity and composition of sugars in tubers are dependent on cultivar, stage of maturity, occurrence of stress, handling and storage management practices. Regulation of sugar levels in tubers by proper production and storage management practices is essential acceptable processing quality (Prichard, 1993). Delgado et al. (2005) demonstrated in their research that field plants treated with 5 or $50 \mathrm{mM}$ hydrogen peroxide significantly enhanced tuber starch accumulation within $6.7 \%$ and $30 \%$, respectively. Also, they found that hydrogen peroxide treated stems were up to $27 \%$ thicker than control plants. and explained that this result mainly due to enlarged medullar parenchyma cells. However, this research was conducted in an attempt to improve potato plant characteristic and tuber quality, i.e., productivity, specific gravity, starch, reducing and total sugars contents to produce acceptable crisp at the end through spraying the field growing plants with some different concentrations of hydrogen peroxide.

\section{MATERIALS AND METHODS}

Three potato cultivars; namely, Lady Rossetta, Valor and Mondial were tested in this investigation during two successive winter seasons of 2010 and 2011. The planting was conducted in the newly reclaimed area in Al-Amria region, Alexandria governorate. This research was existed to test the effect of hydrogen peroxide on the potato yield and tuber quality. Hydrogen peroxide was foliar sprayed once every three days along the growing season starting from the complete plant emergence until the crop maturing. Three doses of hydrogen peroxide $(25,50$ and $75 \mathrm{mM})$ were used in the first season, in addition to the control treatment, which sprayed with water. In the second season, two higher doses; 100 and $125 \mathrm{mM}$ were added to the levels of tested variable. Tubers were planted as a whole, $25 \mathrm{~cm}$ apart in the row, $6.25 \mathrm{~m}$ long and $0.70 \mathrm{~m}$ width.

Each treatment comprised of two rows containing 25 seed tubers each. The experimental plot was $8.75 \mathrm{~m}^{2}$. The plots were under furrow irrigation. It was 
fertilized with $20 \mathrm{~m}^{3}$ of farm manure/ fed. added with soil preparation. It was fertilized with $45 \mathrm{~kg} \mathrm{P}_{2} \mathrm{O}_{5} / \mathrm{fed}$. in the form of super phosphate $15.5 \%$ added within planting in the opened row. Potassium was added at $72 \mathrm{~kg} \mathrm{k}{ }_{2} \mathrm{O} / \mathrm{fed}$. added on there equal doses, within planting, 45 and 60 days after planting. Nitrogen fertilizer added to the crop in $120 \mathrm{~kg} \mathrm{~N} / \mathrm{fed}$. One quarter of the quantity was added within planting in the form of ammonium sulphate. The rest of the quantity was added in 3 equal placements in the form of urea $48 \% \mathrm{~N}$ at, 45, 60 and 75 days after planting. All the agricultural practices for potato production i.e. green sprouting, irrigation, pest disease and weed control were practiced as well. The three tested cultivars were randomly distributed in the block and the spraying with hydrogen peroxide was randomly distributed within each cultivar. The split-plot design in three replicates was used, where potato cultivars were placed in the main plots, while doses of foliar spraying with hydrogen peroxide were occupied the sub-plots.

All the agricultural practices used for commercial potato production, as common in this area, were carried out in both years.

\section{Measurements}

Vegetative growth and yield parameters: average of ten plants/ plot was tested 70 days after planting for measuring plant height $(\mathrm{cm})$, stem diameter $(\mathrm{mm})$ and counting number of main stem / plant. At harvesting time (120 days after planting), the following determinations were estimated: total tuber yield / feddan (ton/ fed.); where the produced tubers per plot were weight and converted into tons/ fed. Average number of tubers/ plant was estimated using the average 10 plants. Number of tubers/ $10 \mathrm{~kg}$ was determined by taking a random sample of 10 $\mathrm{kg}$ of tubers from the yield of each treatment then their tubers were counted. The accepted category is that count $72-112$ tubers in such treatment.

Physical and chemical characteristics: Chlorophyll content was determined using the method of (Grodzinsky and Grodzinsky, 1973) 75 days after planting. Tuber shape index was estimated by dividing the length over the width of the tuber.

Dry matter (\%): was determined by drying the tuber slices at $70^{\circ} \mathrm{C}$ for $24 \mathrm{hr}$ until a constant weight by dividing the (dry weight/ fresh weight) $\times 100$ (Haase, 2003). al. (2005):

Specific gravity: was determined using the method described by Dinesh et Weight of tuber in air

Specific gravity $=$

Weight of tuber in air - weight of tuber under water

Starch (\%); it was determined using the method described by A.O.A.C. (1980) on dry matter basis.

Total and reducing sugars (\%): were determined using the method of Dubios et al. (1956) method on fresh weight basis. 
Crisp net percentage (was recorded only in the first year): where some potato slices were weight and deep fried at $170^{\circ} \mathrm{C}$ and the resulted crisps was weight and related to the fresh weight. Crisps defect evaluation was calculated by showing the size limits $(1 / 2 \mathrm{~cm})$ for sugar browning and defects using chip-check chart method to determine the internal, external and undesirable color defects and dividing the defects to three categories; the first green from $0-8 \%$ defects are acceptable potato chips, the second yellow > $8-15 \%$ defects are acceptable potato chips but with discarding the percentage over $8 \%$ and the third red $>15 \%$ defects are rejected and not suitable for processing according to (Frito Lay Company, 1999).

Histological examination: random samples of tubers were taken from each treatment (three tubers) then peeled and cut with a sharp cork on sliding microtome into slices $1 \mathrm{~mm}$ thickness and $10 \mathrm{~mm}$ in diameter. The slices were mixed and washed with distilled water. Ten randomly slices were examined under a compound microscope using a high power $(400 \mathrm{x})$ objective to determine the parenchyma cell diameter, in micron $(\mu \mathrm{m})$, of potato tubers.

\section{Statistical analysis:}

All the collected data from both years were tabulated and statistically analyzed using analysis of variance technique. Duncan's multiple range test (Steel et al., 1997) was applied to determine the least significant difference (LSD) at $p \leq 0.05$.

\section{RESULTS AND DISCUSSION}

\section{Effect of hydrogen peroxide concentrations on the studied vegetative characters:}

The data presented in (Table 1) appeared that number of stems per plant did not significantly affected with the differences in tested concentrations of hydrogen peroxide $\left(\mathrm{H}_{2} \mathrm{O}_{2}\right)$. Meanwhile, the interaction between the cultivars and the concentrations of $\mathrm{H}_{2} \mathrm{O}_{2}$ was insignificant. Potato plant stem diameter was positively affected with the increasing of $\mathrm{H}_{2} \mathrm{O}_{2}$ concentrations from zero up to 125 $\mathrm{mM}$ during 2010/2011 season. The data showed that there were significant differences among the tested cultivars during the two years of the study. The cultivars Valor and Mondial positively surpassed the cultivar Lady Rosetta in both years of the study. The interaction between potato cultivars and the levels of $\mathrm{H}_{2} \mathrm{O}_{2}$ was significantly noticed in the second season only. Mean diameter of sixth internodes of $\mathrm{H}_{2} \mathrm{O}_{2}$ treated plants was $27 \%(5 \mathrm{mM})$ and $21 \%(50 \mathrm{mM})$ greater than control plants (Delgado et al., 2005). These authors discussed that these results, mainly, taken place due to enlargement of the medullar parenchyma cells. Same trend of results were obtained by Moussa et al. (2012). The results of plant height character showed that spraying potato plants with increased levels of $\mathrm{H}_{2} \mathrm{O}_{2}$, did not significantly affect this character. Same trend of results was, also, noticed for the 
results of the interaction between the tested potato cultivars and the $\mathrm{H}_{2} \mathrm{O}_{2}$ concentrations during both years. Valor cultivar, positively, surpassed both Lady Rosetta and Mondial cultivars in plant height especially in the first season of the study. The results of Moussa et al. (2012) appeared that no significant effect of the concentrations of hydrogen peroxide on the plant height during both years of the study, as well as there were no effects of these concentrations of hydrogen peroxide on the number of branches per plant in the first year of the experiment.

The results of leaves chlorophyll content (Table 1), clearly appeared that neither the tested cultivars, nor hydrogen peroxides treatments, nor the interaction between both factors had the ability to affect the leaves chlorophyll content during the first year of this research. In the second year, there were significant difference effects among the tested cultivars. Lady Rossitta and Valor possessed highly significant values than Mondial cultivar. The tested $\mathrm{H}_{2} \mathrm{O}_{2}$ levels affected the chlorophyll content. The highest mean value was recorded with using $100 \mathrm{mM}$ $\mathrm{H}_{2} \mathrm{O}_{2}$ with insignificant differences effects with both 50 and $125 \mathrm{mM} \mathrm{H}_{2} \mathrm{O}_{2}$. The levels of zero, $25,50,75$ and $125 \mathrm{mM} \mathrm{H}_{2} \mathrm{O}_{2}$ had, significantly, lower values in comparison with the treatment $100 \mathrm{mM} \mathrm{H}_{2} \mathrm{O}_{2}$. As in the first year, the interaction between the cultivars and $\mathrm{H}_{2} \mathrm{O}_{2}$ treatments was not significant. 
J. Adv. Agric. Res. (Fac. Agric. Saba Basha)

Table (1): Mean values' performances of the studied vegetative traits of tested potato cultivars during both years of 2009/2010 and 2010/2011

\begin{tabular}{|c|c|c|c|c|c|c|c|c|c|}
\hline \multicolumn{2}{|c|}{ Seasons } & \multicolumn{4}{|c|}{$2009 / 2010$} & \multicolumn{4}{|c|}{$2010 / 2011$} \\
\hline & Characters & $\begin{array}{c}\text { Plant } \\
\text { height } \\
(\mathrm{cm})\end{array}$ & $\begin{array}{c}\text { No. of } \\
\text { main } \\
\text { stems/p } \\
\text { lant }\end{array}$ & $\begin{array}{l}\text { Stem } \\
\text { diamete } \\
\mathbf{r}(\mathrm{mm})\end{array}$ & $\begin{array}{c}\text { Chloro } \\
\text { phyll } \\
\text { (mg/g } \\
\text { F.W) }\end{array}$ & $\begin{array}{c}\text { Plant } \\
\text { height } \\
\text { (cm) }\end{array}$ & $\begin{array}{c}\text { No. of } \\
\text { main } \\
\text { stems/p } \\
\text { lant }\end{array}$ & $\begin{array}{c}\text { Stem } \\
\text { diamete } \\
\mathbf{r}(\mathrm{mm})\end{array}$ & $\begin{array}{c}\text { Chloro } \\
\text { phyll } \\
\text { (mg/g } \\
\text { F.W) }\end{array}$ \\
\hline \multicolumn{10}{|c|}{ Cultivars } \\
\hline & _ady rosetta & $41.95^{\mathrm{b} *}$ & $3.68^{a}$ & $9.34^{\mathrm{D}}$ & $1.019^{\mathrm{a}}$ & $34.31^{\mathrm{D}}$ & $3.49^{\mathrm{b}}$ & $10.21^{\mathrm{D}}$ & $1.073^{\mathrm{a}}$ \\
\hline & Valor & $46.10^{\mathrm{a}}$ & $5.15_{a}$ & $10.45_{a}$ & $1.006^{\mathrm{a}}$ & $40.54^{a}$ & $4.73^{\mathrm{a}}$ & $11.02^{\mathrm{a}}$ & $1.075^{\mathrm{a}}$ \\
\hline & Mondial & $40.06^{\mathrm{b}}$ & $4.66^{\mathrm{a}}$ & $10.11^{\mathrm{a}}$ & $0.992^{\mathrm{a}}$ & $34.07^{\mathrm{b}}$ & $4.63^{\mathrm{a}}$ & $10.84^{\mathrm{a}}$ & $1.046^{\mathrm{b}}$ \\
\hline \multicolumn{10}{|c|}{$\mathrm{H}_{2} \mathrm{O}_{2}$ Concentration } \\
\hline & Control & $41.46^{\mathrm{a}}$ & $4.47^{\mathrm{a}}$ & $8.89^{a}$ & $0.991^{\mathrm{a}}$ & $35.82^{a}$ & $4.13^{\mathrm{a}}$ & $9.50^{\mathrm{d}}$ & $1.053^{\mathrm{b}}$ \\
\hline & $25 \mathrm{mM}$ & $43.41^{\mathrm{a}}$ & $4.62^{\mathrm{a}}$ & $9.62^{\mathrm{C}}$ & $1.014^{\mathrm{a}}$ & $36.41^{a}$ & $4.03^{\mathrm{a}}$ & $9.76^{\mathrm{d}}$ & $1.038^{\mathrm{b}}$ \\
\hline & $50 \mathrm{mM}$ & $42.62^{\mathrm{a}}$ & $4.40^{\mathrm{a}}$ & $10.32^{\mathrm{b}}$ & $1.010^{\mathrm{a}}$ & $35.80^{\mathrm{a}}$ & $4.69^{a}$ & $10.40^{\mathrm{C}}$ & $1.068^{\mathrm{ab}}$ \\
\hline & $75 \mathrm{mM}$ & $42.46_{a}$ & $4.49^{\mathrm{a}}$ & $11.03^{\mathrm{a}}$ & $1.010^{\mathrm{a}}$ & $36.66^{a}$ & $4.17^{\mathrm{a}}$ & $10.97^{\mathrm{D}}$ & $1.045^{\mathrm{b}}$ \\
\hline & $100 \mathrm{mM}$ & --- & --- & --- & ---- & $36.83^{a}$ & $4.36^{\mathrm{a}}$ & $11.71^{\mathrm{a}}$ & $1.119^{\mathrm{a}}$ \\
\hline & $125 \mathrm{mM}$ & ---- & ---- & --- & ---- & $36.31^{a}$ & $4.32^{a}$ & $11.80^{\mathrm{a}}$ & $1.066^{\mathrm{ab}}$ \\
\hline \multicolumn{10}{|c|}{ Cultivars $\mathrm{x}_{2} \mathrm{O}_{2}$ Concentration } \\
\hline \multirow{6}{*}{ 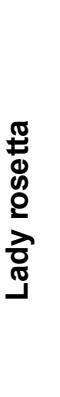 } & Control & $42.7^{a}$ & $3.8^{a}$ & $8.1^{\mathrm{a}}$ & $1.032^{\mathrm{a}}$ & $33.4^{\mathrm{a}}$ & $2.8^{\mathrm{a}}$ & $8.9^{a}$ & $1.092^{\mathrm{a}}$ \\
\hline & $25 \mathrm{mM}$ & $40.4^{a}$ & $3.7^{\mathrm{a}}$ & $9.1^{\mathrm{a}}$ & $1.014^{\mathrm{a}}$ & $34.8^{\mathrm{a}}$ & $3.3^{\mathrm{a}}$ & $8.9^{a}$ & $1.085^{\mathrm{a}}$ \\
\hline & $50 \mathrm{mM}$ & $40.6^{a}$ & $3.5^{\mathrm{a}}$ & $9.8^{\mathrm{a}}$ & $1.086^{a}$ & $33.3^{\mathrm{a}}$ & $3.9^{\mathrm{a}}$ & $10.0^{\mathrm{cd}}$ & $1.093^{a}$ \\
\hline & $75 \mathrm{mM}$ & $41.7^{\mathrm{a}}$ & $3.7^{\mathrm{a}}$ & $10.3^{a}$ & $0.947^{\mathrm{a}}$ & $35.2^{\mathrm{a}}$ & $3.7^{\mathrm{a}}$ & $10.3^{c}$ & $1.054^{\mathrm{a}}$ \\
\hline & $100 \mathrm{mM}$ & --- & ---- & --- & --- & $34.9^{\mathrm{a}}$ & $3.8^{\mathrm{a}}$ & $11.3^{\mathrm{b}}$ & $1.110^{\mathrm{a}}$ \\
\hline & $125 \mathrm{mM}$ & --- & ---- & --- & ---- & $34.3^{\mathrm{a}}$ & $3.4^{\mathrm{a}}$ & $11.7^{\mathrm{ab}}$ & $1.007^{\mathrm{a}}$ \\
\hline \multirow{5}{*}{$\frac{\frac{1}{7}}{>}$} & Control & $42.9^{a}$ & $5.3^{a}$ & $9.3^{\mathrm{a}}$ & $1.005^{\mathrm{a}}$ & $41.0^{a}$ & $4.9^{\mathrm{a}}$ & $10.1^{\mathrm{cd}}$ & $1.049^{a}$ \\
\hline & $25 \mathrm{mM}$ & $48.9^{a}$ & $5.2^{\mathrm{a}}$ & $10.1^{a}$ & $1.005^{\mathrm{a}}$ & $41.1^{a}$ & $4.7^{\mathrm{a}}$ & $10.5^{c}$ & $1.045^{\mathrm{a}}$ \\
\hline & $50 \mathrm{mM}$ & $45.4^{\mathrm{a}}$ & $4.6^{\mathrm{a}}$ & $10.9^{a}$ & $0.969^{a}$ & $38.9^{a}$ & $5.2^{\mathrm{a}}$ & $10.7^{\mathrm{bc}}$ & $1.084^{a}$ \\
\hline & $75 \mathrm{mM}$ & $47.2^{\mathrm{a}}$ & $5.4^{\mathrm{a}}$ & $11.5^{\mathrm{a}}$ & $1.047^{\mathrm{a}}$ & $40.5^{a}$ & $4.2^{\mathrm{a}}$ & $11.2^{\mathrm{D}}$ & $1.046^{a}$ \\
\hline & $100 \mathrm{mM}$ & --- & --- & ---- & ---- & $41.5^{a}$ & $4.7^{\mathrm{a}}$ & $11.9^{a}$ & $1.117^{a}$ \\
\hline
\end{tabular}


J. Adv. Agric. Res. (Fac. Agric. Saba Basha)

\begin{tabular}{|c|c|c|c|c|c|c|c|c|c|}
\hline & $125 \mathrm{mM}$ & --- & ---- & --- & ---- & $40.2^{a}$ & $4.7^{\mathrm{a}}$ & $11.8^{\mathrm{ab}}$ & $1.114^{\mathrm{a}}$ \\
\hline \multirow{6}{*}{$\begin{array}{l}\overline{\bar{\sigma}} \\
\overline{\underline{\underline{0}}} \\
\overline{0} \\
\bar{\Sigma}\end{array}$} & Control & $38.8^{a}$ & $4.3^{\mathrm{a}}$ & $9.3^{a}$ & $0.936^{a}$ & $33.1^{a}$ & $4.7^{\mathrm{a}}$ & $9.5^{\mathrm{a}}$ & $1.020^{\mathrm{a}}$ \\
\hline & $25 \mathrm{mM}$ & $40.9^{a}$ & $4.9^{\mathrm{a}}$ & $9.6^{a}$ & $1.025^{\mathrm{a}}$ & $33.3^{\mathrm{a}}$ & $4.1^{\mathrm{a}}$ & $9.9^{\mathrm{cd}}$ & $0.984^{\mathrm{a}}$ \\
\hline & $50 \mathrm{mM}$ & $40.7^{\mathrm{a}}$ & $5.1^{\mathrm{a}}$ & $10.2^{\mathrm{a}}$ & $0.975^{\mathrm{a}}$ & $35.2^{\mathrm{a}}$ & $4.9^{\mathrm{a}}$ & $10.5^{c}$ & $1.028^{\mathrm{a}}$ \\
\hline & $75 \mathrm{mM}$ & $39.8^{\mathrm{a}}$ & $4.3^{a}$ & $11.3^{\mathrm{a}}$ & $1.035^{\mathrm{a}}$ & $34.2^{\mathrm{a}}$ & $4.6^{a}$ & $11.4^{\mathrm{ab}}$ & $1.036^{\mathrm{a}}$ \\
\hline & $100 \mathrm{mM}$ & --- & --- & ---- & --- & $34.2^{a}$ & $4.6^{a}$ & $11.9^{\mathrm{a}}$ & $1.131^{\mathrm{a}}$ \\
\hline & $125 \mathrm{mM}$ & --- & ---- & --- & ---- & $34.5^{\mathrm{a}}$ & $4.6^{\mathrm{a}}$ & $11.9^{\mathrm{a}}$ & $1.078^{\mathrm{a}}$ \\
\hline
\end{tabular}

$\overline{{ }^{*} \text { Values with an alphabetical letter, in a comparable group of means, don't differ }}$ significantly from one another using Duncan's Multiple Range Test, at 0.05 level of significance.

----, not treated during the first year

\section{Effect of hydrogen peroxide concentrations on potato yield and its component characters:}

Total potato yield (ton/ fed.) was significantly affected by the tesyed cultivar (Table 2) during both years. In the first year, Mondial and Valor cultivars over cropped Lady Rosseta, significantly. In the second year, the Valor cultivar surpassed the other two cultivars, significantly. The results showed that the $\mathrm{H}_{2} \mathrm{O}_{2}$ concentrations did not amend the potato tuber yield, in the first season. The data of the second season appeared that the levels $25,50,75 \mathrm{mM}$ of $\mathrm{H}_{2} \mathrm{O}_{2}$ did not differ in their productivities with the control treatment. The other two high levels (100 and $125 \mathrm{mM}$ ) of $\mathrm{H}_{2} \mathrm{O}_{2}$ resulted in lower potato yields. The interaction effect between cultivars and $\mathrm{H}_{2} \mathrm{O}_{2}$ was highly significant for both seasons of this research. Moussa et al. (2012) declared that the highest productivity was obtained as a result of spraying $\mathrm{H}_{2} \mathrm{O}_{2}$ at $40 \mathrm{mM}$, followed by $60 \mathrm{mM}$. Data presented for number of tubers per plant showed that the cultivar Valor exceeded the other two cultivars all over both years of the study. Non- of the tested hydrogen peroxide levels in the first season resulted in insignificant effect on number of tubers per plant. The results of the second seasons declared that the level of $125 \mathrm{mM} \mathrm{H}_{2} \mathrm{O}_{2}$ produced the highest number of tubers per plant without significant differences with the levels 25,50 , $75,100 \mathrm{mM}$ of $\mathrm{H}_{2} \mathrm{O}_{2}$. The control treatment (zero level of $\mathrm{H}_{2} \mathrm{O}_{2}$ ) recorded the lowest mean value without significant differences with the levels $25,50,75,100 \mathrm{mM}$ of $\mathrm{H}_{2} \mathrm{O}_{2}$. No interaction effect was found to change tuber number of plants in the first year. On the other hand, the interaction was found to be highly significant effects on such character in the second year of this investigation. The results of Romero and Lopez-Delgado (2009) detected that the treated plants with $\mathrm{H}_{2} \mathrm{O}_{2}$ and antioxidant such as ascorbic acid lead to reduce the number of mini- tubers, while enhancing their weights and starch content. Moussa et al. (2012) pointed that increasing the concentration of $\mathrm{H}_{2} \mathrm{O}_{2}$ led to positive effect on the number of tubers

Vol. 19 (1), 2014 
per plant. Average tuber weight of "Lady Rossitta" cv. was the significantly lower among the tested cultivars in both seasons of the experiment (Table 2). Nonsignificant differences between "Valor and Mondial" cv. in the average tuber weight in both seasons were detected.

Hydrogen peroxide levels did not show any significant difference effects on the average tuber weight during both years of the study. No interaction effect between $\mathrm{H}_{2} \mathrm{O}_{2}$ level and potato cultivar was noticed to enlarge the average tuber weight character. Gutierrez et al. (2012) reported that $\mathrm{H}_{2} \mathrm{O}_{2}$ treatment induced higher internal $\mathrm{H}_{2} \mathrm{O}_{2}$ concentration, which was associated with positive effects on tuber weight, starch content and reduction tuber number. The number of tubers per $10 \mathrm{~kg}$ was recorded. This character indicates the suitability of potato cultivars for chipping. There is general agreement among potato processors to use this record. It ranks between $72-112$ tubers/ $10 \mathrm{~kg}$ of potatoes, less than 72 tubers/ $10 \mathrm{~kg}$ indicate that the tubers are too large for processing. Data of (Table 2) revealed that in the first season of the study. All the studied cultivars were in the acceptable range of this record, meaning that all the tested cultivars are acceptable for potato processing, with some significant differences among them. In the second season, all the tested cultivars did not meet the acceptable record for number of tubers/ 10 $\mathrm{kg}$, in which it was above the accepted number. The interaction effect was clearly noticed to amend the number of tubers/ $10 \mathrm{~kg}$ trait.

Table (2): Mean values' performances of yield and yield components of tested potato cultivars during both years of 2009/2010 and 2010/2011

\begin{tabular}{|c|c|c|c|c|c|c|c|c|c|c|}
\hline \multirow{2}{*}{$\begin{array}{l}\text { Seasons } \\
\text { Characters }\end{array}$} & \multicolumn{5}{|c|}{$2009 / 2010$} & \multicolumn{5}{|c|}{$2010 / 2011$} \\
\hline & $\begin{array}{l}\text { No. of } \\
\text { tubers/ } \\
\text { Plant }\end{array}$ & $\begin{array}{c}\text { Avr. } \\
\text { tuber } \\
\text { weight( } \\
\text { gm) }\end{array}$ & $\begin{array}{c}\text { Crop } \\
\text { yield } \\
\text { (ton/fed.) }\end{array}$ & $\begin{array}{l}\text { Tuber } \\
\text { shape } \\
\text { index }\end{array}$ & $\begin{array}{c}\text { No. of } \\
\text { tuberl } \\
10 \mathrm{~kg}\end{array}$ & $\begin{array}{l}\text { No. of } \\
\text { tubers/ } \\
\text { plant }\end{array}$ & $\begin{array}{l}\text { Avr. tuber } \\
\text { weight } \\
\text { (gm) }\end{array}$ & $\begin{array}{c}\text { Crop } \\
\text { yield } \\
\text { (ton/fed.) }\end{array}$ & $\begin{array}{l}\text { Tuber } \\
\text { shape } \\
\text { index }\end{array}$ & $\begin{array}{c}\text { No. of } \\
\text { tuberl } \\
10 \mathrm{~kg}\end{array}$ \\
\hline \multicolumn{11}{|c|}{ Cultivars } \\
\hline Lady rosetta & $9.2^{\mathrm{b}^{*}}$ & $34.5^{\mathrm{b}}$ & $16.16^{\mathrm{b}}$ & $0.96^{\mathrm{c}}$ & $109.5^{\mathrm{a}}$ & $7.9^{b}$ & $49.93^{b}$ & $5.40^{\mathrm{C}}$ & $0.94^{\mathrm{c}}$ & $199.9^{a}$ \\
\hline Valor & $10.6^{a}$ & $53.6^{a}$ & $20.70^{a}$ & $1.12^{b}$ & $86.1^{b}$ & $8.2^{a}$ & $70.01^{a}$ & $9.20^{\mathrm{a}}$ & $1.04^{b}$ & $121.6^{c}$ \\
\hline Mondial & $9.9 a b$ & $66.6 a$ & $21.40 a$ & $1.44 a$ & $78.7 \mathrm{c}$ & $7.3 \mathrm{c}$ & $77.38 a$ & $7.02 b$ & $1.36 a$ & $135.7 \mathrm{~b}$ \\
\hline \multicolumn{11}{|c|}{$\mathrm{H}_{2} \mathrm{O}_{2}$ Concentration } \\
\hline Control & $9.8^{\mathrm{a}}$ & $53.3^{\mathrm{a}}$ & $19.37^{\mathrm{a}}$ & $1.19^{a}$ & $86.7^{\mathrm{b}}$ & $7.4^{\mathrm{b}}$ & $60.48^{\mathrm{a}}$ & $7.51^{\mathrm{a}}$ & $1.10^{\mathrm{a}}$ & $140.2^{\mathrm{C}}$ \\
\hline $25 \mathrm{mM}$ & $9.8^{\mathrm{a}}$ & $53.2^{a}$ & $19.77^{\mathrm{a}}$ & $1.14^{b}$ & $91.1^{\mathrm{ab}}$ & $7.8^{\mathrm{ab}}$ & $64.53^{a}$ & $8.03^{a}$ & $1.11^{a}$ & $156.7^{\mathrm{ab}}$ \\
\hline $50 \mathrm{mM}$ & $9.9^{\mathrm{a}}$ & $49.0^{a}$ & $19.33^{a}$ & $1.18^{a}$ & $95.8^{a}$ & $7.6^{\mathrm{ab}}$ & $69.38^{a}$ & $7.70^{\mathrm{a}}$ & $1.12^{a}$ & $140.2^{c}$ \\
\hline $75 \mathrm{mM}$ & $10.2^{\mathrm{a}}$ & $50.8^{a}$ & $19.21^{\mathrm{a}}$ & $1.18^{a}$ & $92.2^{\mathrm{ab}}$ & $7.8^{\mathrm{ab}}$ & $70.8^{4 a}$ & $7.66^{a}$ & $1.11^{\mathrm{a}}$ & $152.0^{b}$ \\
\hline $100 \mathrm{mM}$ & ---- & --- & ---- & --- & --- & $7.9^{\mathrm{ab}}$ & $69.49^{a}$ & $5.77^{c}$ & $1.13^{a}$ & $153.1^{\mathrm{ab}}$ \\
\hline
\end{tabular}


J. Adv. Agric. Res. (Fac. Agric. Saba Basha)

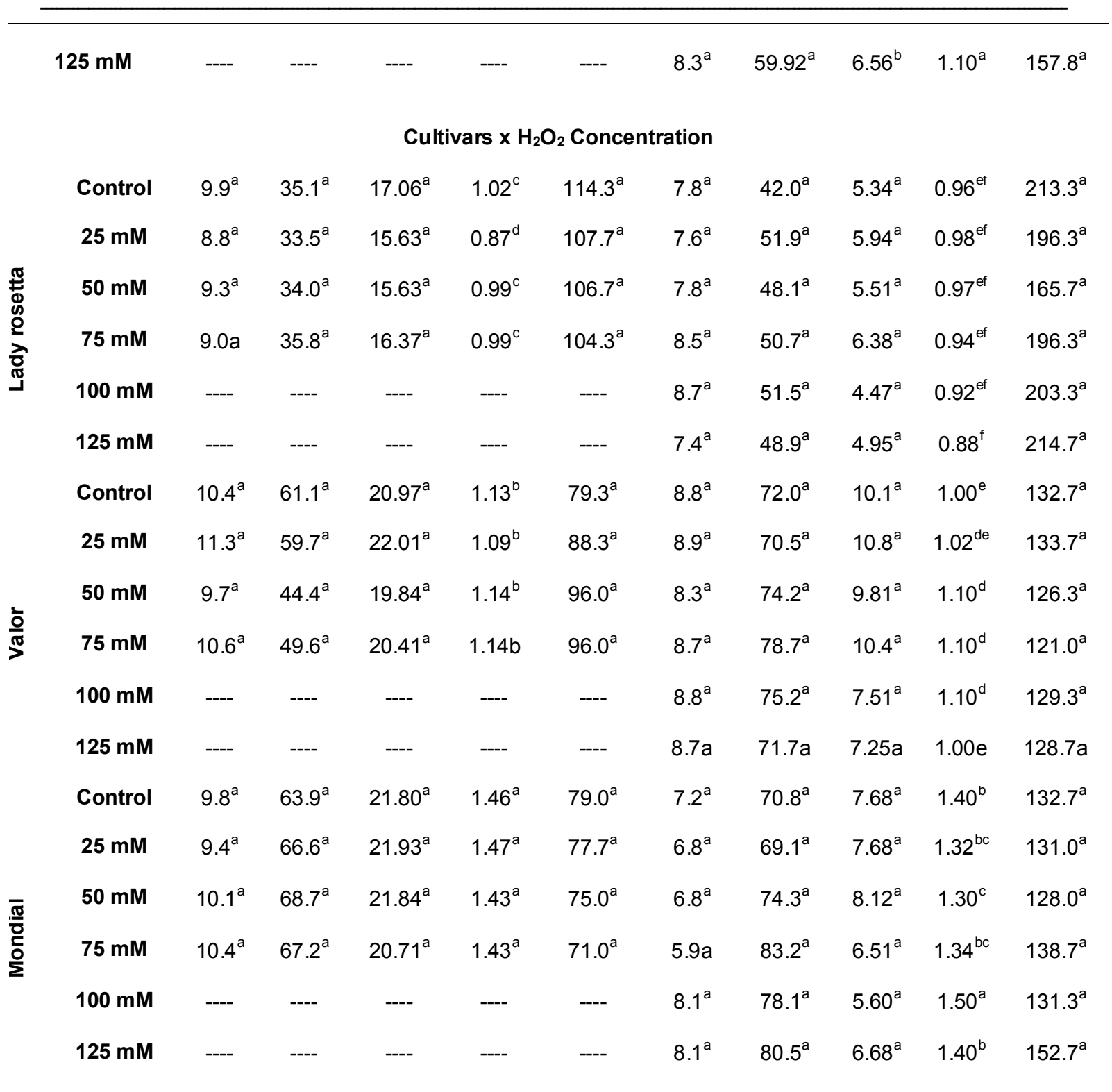

*Values with an alphabetical letter, in a comparable group of means, don't differ significantly from one another using Duncan's Multiple Range Test, at 0.05 level of significance.

----, not treated during the first year

\section{Effect of hydrogen peroxide concentrations on potato physical, chemical and quality characters:}

Mondial cultivar showed the biggest mean value of tuber shape index among the studied cultivars in both years (Table 3 ). This means that this cultivar has more long tubers than the others. The data recorded that in the first season 25 $\mathrm{mM}$ of hydrogen peroxide resulted in significant difference than the other 
treatments, in which it decreased the tuber shape index. This means that the tuber became more round than the other treatments. In the second season, $\mathrm{H}_{2} \mathrm{O}_{2}$ concentrations had nothing to do with the tuber shape index. The interaction was only significant in the second year of the study. Specific gravity of tubers of Lady Rossitta cultivar was the highest among all the studied cultivars in both seasons (Table 3).

Kunkel et al. (1951) and Lana et al. (1970) reported that specific gravity of row potato is widely accepted by the potato processing industry as a measure of total solids, starch concentration and other qualities. Neither the tested $\mathrm{H}_{2} \mathrm{O}_{2}$ nor its interaction with potato cultivar had the capacity to change potato tuber specific gravity in the study. Moussa et al. (2012) detected that the specific gravity trait was positively affected with foliar application with $\mathrm{H}_{2} \mathrm{O}_{2}$ compared with the untreated plants. Tuber dry matter was significantly affected by potato cultivar in both seasons of the study (Table 3). "Lady Rossitta" cultivar was the significantly higher one in dry matter content in both seasons. "Valor" cultivar ranked the second in dry matter content after "Lady Rossitta" in the second season. This result may point to that "Lady Rossitta" is the more suitable cultivar among the tested cultivars in chipping industry. Duran et al, (2007) stated that dry matter is particularly important in the production of potato chip because of greater surface area to volume ratio in chips compared with fries. Stevenson et al. (1964) explained that dry matter concentration of tubers is an important measure of quality to assess suitability for processing purpose as it influence process efficiency, product yield and oil absorption. None of the studied levels of $\mathrm{H}_{2} \mathrm{O}_{2}$ treatments and their interactions with potato cultivars showed significant effect on potato tuber dry matter content during the second year of this study. In the first year, the data of (Table 3), appeared that spraying potato plants with 70 or $50 \mathrm{mM}$ of $\mathrm{H}_{2} \mathrm{O}_{2}$ significantly increased dry matter percentage compared with the control treatment. Delgado et al. (2005) reported that $\mathrm{H}_{2} \mathrm{O}_{2}$ used to spray potato plants and lead to increase dry matter. "Lady Rossitta" cv. showed the highest significant level of starch content compared with the other tested cultivars (Table 3 ) during both years of this investigation. "Valor" cv. was not significantly different than "Mondial" cv. in the first year. In the second year, there was significantly difference between these two previous cultivars. "Mondial" cv. came the third one in this respect. This result may be related to the cultivars differences. This result may point to that "Valor" cv. is more suitable than both others cultivars to be used in crisp production depending on its starch content. Owing to its economic importance, potato tuber starch has the subject of considerable research effort, with an accelerating rate of progress in recent years. The data cleared that there were pronounced effects noticed as a result of hydrogen peroxide on potato tuber starch content. Both treatments 75 and $50 \mathrm{mM}$ of $\mathrm{H}_{2} \mathrm{O}_{2}$ produced the highest levels of tuber starch content in the first year of the study. Spraying potato plants with $75 \mathrm{mM}$ of hydrogen peroxide produced the highly tuber starch content with significant differences among the other tested treatment in the second year of the study. No interaction effects were found between cultivar and $\mathrm{H}_{2} \mathrm{O}_{2}$ level to change tuber starch contents during both seasons of this study. Generally, it could be calculated that spraying growing plants 
with the concentration of $75 \mathrm{mM} \mathrm{H}_{2} \mathrm{O}_{2}$ gave the highest values of potato tuber quality. Total sugars were not affected by neither potato cultivar nor $\mathrm{H}_{2} \mathrm{O}_{2}$ concentration or their interaction during the first season. The differences among potato cultivars were found only in the second season, as well as the differences among the $\mathrm{H}_{2} \mathrm{O}_{2}$ concentrations. The interaction was not affected significantly. Reducing sugars content did affect neither $\mathrm{H}_{2} \mathrm{O}_{2}$ concentrations nor the interaction between potato cultivar and $\mathrm{H}_{2} \mathrm{O}_{2}$ concentration in the present study. The significance in total sugars was only detected among the tested cultivars. Reducing sugars of "Valor" cv. showed higher significantly value than the other tested cultivars in the first season of the study. "Lady Rossitta" possessed the highest significant value for reducing sugars comparable with valor and Mondial cultivars during the second season. Talburt and Smith (1987) claimed that level of reducing sugars is one among of the four primary factors determining French fry quality. French fry color is largely determine by the reducing sugars content of the potato tuber; potatoes with high reducing sugars level make dark fries, when potatoes are fried, the reducing sugars react with amino acids in the tuber to form dark products in amino-enzymes browning reaction. The concentration of reducing sugars in the potato tuber depends on cultivar, growing conditions, maturing and storage conditions (Surmacka, 2002). As with French fries, the color of potato chips depends on the reducing sugars content of the potato (Biedermann, 2003). However, potato chip processors have slightly loss control over reducing sugars levels because blenching is not option in chipping process. The net crisp product of Mondial exceeded Lady Rossitta and Valor, significantly (Table 4). Likely, "Lady Rossitta" produced much net crisp than Valor. This result means that the high net crisp production cultivar is desired by the potato processors because the cost production will be reduced. Potato crisp have been popular salty snacks for ISO years and it sale in USA are about 6 \$ billion/ year, repressing 33\% of the total sales of their market (Gurayo and Moreira, 2000 and Clarke, 2003). Applying $\mathrm{H}_{2} \mathrm{O}_{2}$ at 25 or $50 \mathrm{mM}$ increased the net crisp production. Application of $75 \mathrm{mM}$ slightly reduced the net crisp production significantly than 25 or $50 \mathrm{mM}$ treatments. The control treatment was significantly differed than any of the tested $\mathrm{H}_{2} \mathrm{O}_{2}$ levels used in this study. It gave the lowest net crisp percentage. No interaction effect was noticed between potato cultivars and the levels of $\mathrm{H}_{2} \mathrm{O}_{2}$ to change the net crisp production. 
J. Adv. Agric. Res. (Fac. Agric. Saba Basha)

Table (3): Mean values' performances of tuber quality characteristics of tested potato cultivars during both years of 2009/2010 and 2010/2011

\begin{tabular}{|c|c|c|c|c|c|c|c|c|c|c|c|}
\hline \multirow{2}{*}{\multicolumn{2}{|c|}{$\begin{array}{l}\text { Seasons } \\
\text { Characters }\end{array}$}} & \multicolumn{5}{|c|}{$2009 / 2010$} & \multicolumn{5}{|c|}{$2010 / 2011$} \\
\hline & & Starch\% & $\begin{array}{c}\text { Total } \\
\text { Sugars } \\
\%\end{array}$ & $\begin{array}{c}\text { Reduce } \\
\text { Sugars } \\
\%\end{array}$ & $\begin{array}{c}\text { Dry } \\
\text { matter } \\
\%\end{array}$ & $\begin{array}{l}\text { Specific } \\
\text { Gravity }\end{array}$ & Starch\% & $\begin{array}{c}\text { Total } \\
\text { Sugars } \\
\%\end{array}$ & $\begin{array}{c}\text { Reduce } \\
\text { Sugars } \\
\%\end{array}$ & $\begin{array}{c}\text { Dry } \\
\text { matter } \\
\%\end{array}$ & $\begin{array}{l}\text { Specific } \\
\text { Gravity }\end{array}$ \\
\hline \multicolumn{12}{|c|}{ Cultivars } \\
\hline & ady rosetta & $14.62^{\mathrm{a}^{*}}$ & $6.8^{\mathrm{a}}$ & $3.56^{\mathrm{ab}}$ & $23.1^{a}$ & $1.089^{\mathrm{a}}$ & $10.50^{\mathrm{a}}$ & $11.7^{\mathrm{c}}$ & $4.97^{\mathrm{a}}$ & $18.8^{\mathrm{a}}$ & $1.074^{\mathrm{a}}$ \\
\hline & Valor & $12.94^{\mathrm{b}}$ & $7.3^{\mathrm{a}}$ & $4.10^{\mathrm{a}}$ & $19.1^{\mathrm{c}}$ & $1.078^{\mathrm{b}}$ & $10.10^{\mathrm{b}}$ & $12.5^{\mathrm{a}}$ & $4.55^{\mathrm{b}}$ & $18.2^{\mathrm{b}}$ & $1.071^{\mathrm{b}}$ \\
\hline & Mondial & $12.91^{\mathrm{D}}$ & $7.4^{\mathrm{a}}$ & $3.37^{\mathrm{D}}$ & $19.9^{\mathrm{D}}$ & $1.078^{\mathrm{D}}$ & $9.04^{c}$ & $11.9^{\mathrm{D}}$ & $4.27^{\mathrm{D}}$ & $17.5^{\mathrm{c}}$ & $1.067^{\mathrm{c}}$ \\
\hline \multicolumn{12}{|c|}{$\mathrm{H}_{2} \mathrm{O}_{2}$ Concentration } \\
\hline & Control & $13.13^{b}$ & $7.1^{\mathrm{a}}$ & $3.56^{\mathrm{a}}$ & $20.1^{\mathrm{b}}$ & $1.081^{\mathrm{a}}$ & $10.10^{b}$ & $12.0^{\mathrm{b}}$ & $4.36^{\mathrm{a}}$ & $17.9^{\mathrm{a}}$ & $1.070^{\mathrm{a}}$ \\
\hline & $25 \mathrm{mM}$ & $13.42^{\mathrm{b}}$ & $7.0^{\mathrm{a}}$ & $3.82^{\mathrm{a}}$ & $20.7^{\mathrm{ab}}$ & $1.082^{\mathrm{a}}$ & $9.73^{b}$ & $12.1^{\mathrm{b}}$ & $4.31^{\mathrm{a}}$ & $18.2^{\mathrm{a}}$ & $1.071^{\mathrm{a}}$ \\
\hline & $50 \mathrm{mM}$ & $13.10^{\mathrm{D}}$ & $7.1^{\mathrm{a}}$ & $3.66^{a}$ & $21.0^{a}$ & $1.082^{\mathrm{a}}$ & $10.10^{\mathrm{D}}$ & $13.1^{\mathrm{a}}$ & $4.41^{\mathrm{a}}$ & $18.1^{\mathrm{a}}$ & $1.070^{\mathrm{a}}$ \\
\hline & $75 \mathrm{mM}$ & $14.31^{\mathrm{a}}$ & $7.5^{\mathrm{a}}$ & $3.67^{a}$ & $21.0^{a}$ & $1.082^{\mathrm{a}}$ & $10.85^{\mathrm{a}}$ & $11.8^{\mathrm{D}}$ & $4.53^{\mathrm{a}}$ & $18.1^{\mathrm{a}}$ & $1.070^{\mathrm{a}}$ \\
\hline & $100 \mathrm{mM}$ & ---- & --- & ---- & ---- & ---- & $9.15^{\mathrm{c}}$ & $12.2^{\mathrm{b}}$ & $5.04^{\mathrm{a}}$ & $18.2^{\mathrm{a}}$ & $1.071^{\mathrm{a}}$ \\
\hline & $125 \mathrm{mM}$ & --- & --- & --- & --- & --- & $9.45^{\mathrm{c}}$ & $11.0^{c}$ & $4.94^{\mathrm{a}}$ & $18.3^{a}$ & $1.071^{\mathrm{a}}$ \\
\hline \multicolumn{12}{|c|}{ Cultivars $\times \mathrm{H}_{2} \mathrm{O}_{2}$ Concentration } \\
\hline \multirow{6}{*}{ 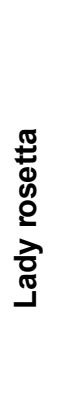 } & Control & $14.35^{\mathrm{a}}$ & $6.5^{\mathrm{a}}$ & $3.0^{\mathrm{a}}$ & $23.3^{a}$ & $1.087^{\mathrm{a}}$ & $10.70^{a}$ & $11.4^{\mathrm{a}}$ & $4.51^{\mathrm{a}}$ & $18.7^{\mathrm{a}}$ & $1.073^{\mathrm{a}}$ \\
\hline & $25 \mathrm{mM}$ & $14.55^{\mathrm{a}}$ & $6.8^{\mathrm{a}}$ & $3.7^{\mathrm{a}}$ & $23.1^{\mathrm{a}}$ & $1.087^{\mathrm{a}}$ & $9.80^{a}$ & $11.4^{\mathrm{a}}$ & $4.31^{\mathrm{a}}$ & $19.0^{\mathrm{a}}$ & $1.074^{\mathrm{a}}$ \\
\hline & $50 \mathrm{mM}$ & $14.10^{\mathrm{a}}$ & $6.9^{\mathrm{a}}$ & $3.6^{\mathrm{a}}$ & $23.0^{a}$ & $1.089^{\mathrm{a}}$ & $10.70^{\mathrm{a}}$ & $11.4^{\mathrm{a}}$ & $4.58^{\mathrm{a}}$ & $18.8^{a}$ & $1.070^{\mathrm{a}}$ \\
\hline & $75 \mathrm{mM}$ & $15.50^{a}$ & $7.0^{\mathrm{a}}$ & $3.5^{\mathrm{a}}$ & $23.1^{a}$ & $1.089^{\mathrm{a}}$ & $11.40^{\mathrm{a}}$ & $12.4^{\mathrm{a}}$ & $5.61^{a}$ & $18.8^{a}$ & $1.073^{\mathrm{a}}$ \\
\hline & $100 \mathrm{mM}$ & ---- & --- & ---- & --- & --- & $10.00^{\mathrm{a}}$ & $12.6^{\mathrm{a}}$ & $5.02^{a}$ & $18.6^{a}$ & $1.073^{\mathrm{a}}$ \\
\hline & $125 \mathrm{mM}$ & ---- & --- & ---- & ---- & --- & $10.50^{\mathrm{a}}$ & $11.0^{\mathrm{a}}$ & $5.80^{\mathrm{a}}$ & $19.0^{\mathrm{a}}$ & $1.075^{\mathrm{a}}$ \\
\hline \multirow{6}{*}{$\frac{\frac{1}{0}}{\frac{\pi}{\pi}}$} & Control & $12.95^{\mathrm{a}}$ & $7.5^{\mathrm{a}}$ & $3.9^{\mathrm{a}}$ & $18.6^{a}$ & $1.077^{\mathrm{a}}$ & $10.40^{\mathrm{a}}$ & $12.7^{\mathrm{a}}$ & $4.18^{a}$ & $18.0^{a}$ & $1.070^{\mathrm{a}}$ \\
\hline & $25 \mathrm{mM}$ & $12.60^{\mathrm{a}}$ & $7.3^{\mathrm{a}}$ & $3.5^{\mathrm{a}}$ & $19.6^{a}$ & $1.076^{\mathrm{a}}$ & $10.50^{\mathrm{a}}$ & $13.5^{\mathrm{a}}$ & $5.07^{a}$ & $17.9^{a}$ & $1.069^{\mathrm{a}}$ \\
\hline & $50 \mathrm{mM}$ & $12.60^{a}$ & $7.4^{\mathrm{a}}$ & $3.9^{\mathrm{a}}$ & $19.0^{a}$ & $1.077^{\mathrm{a}}$ & $10.20^{\mathrm{a}}$ & $13.5^{\mathrm{a}}$ & $4.20^{a}$ & $18.1^{\mathrm{a}}$ & $1.071^{\mathrm{a}}$ \\
\hline & $75 \mathrm{mM}$ & $13.60^{a}$ & $7.3^{\mathrm{a}}$ & $3.7^{\mathrm{a}}$ & $19.3^{a}$ & $1.078^{\mathrm{a}}$ & $11.65^{\mathrm{a}}$ & $12.7^{\mathrm{a}}$ & $4.26^{a}$ & $18.5^{a}$ & $1.072^{\mathrm{a}}$ \\
\hline & $100 \mathrm{mM}$ & ---- & --- & ---- & ---- & --- & $9.15^{\mathrm{a}}$ & $11.4^{\mathrm{a}}$ & $4.72^{a}$ & $18.1^{a}$ & $1.072^{a}$ \\
\hline & $125 \mathrm{mM}$ & ---- & --- & ---- & ---- & --- & $8.70^{a}$ & $10.8^{a}$ & $4.90^{\mathrm{a}}$ & $18.3^{a}$ & $1.071^{\mathrm{a}}$ \\
\hline
\end{tabular}


J. Adv. Agric. Res. (Fac. Agric. Saba Basha)

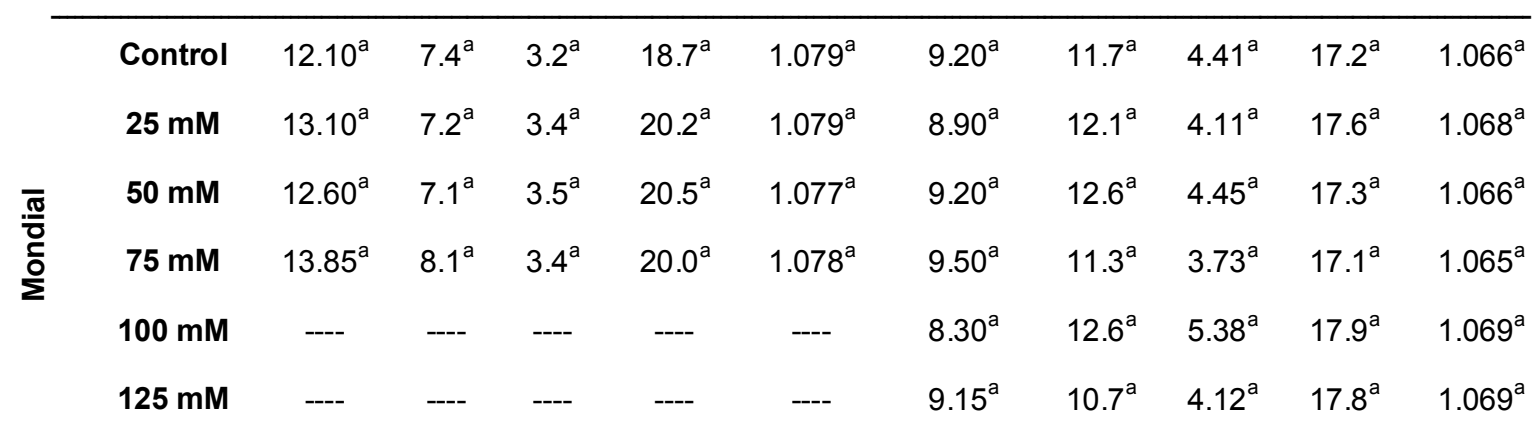

${ }^{*}$ Values with an alphabetical letter, in a comparable group of means, don't differ significantly from one another using Duncan's Multiple Range Test, at 0.05 level of significance

----, not treated during the first year

Table (4): Means values' performances of the net crisp production of tested potato cultivars during winter season of 2009/2010

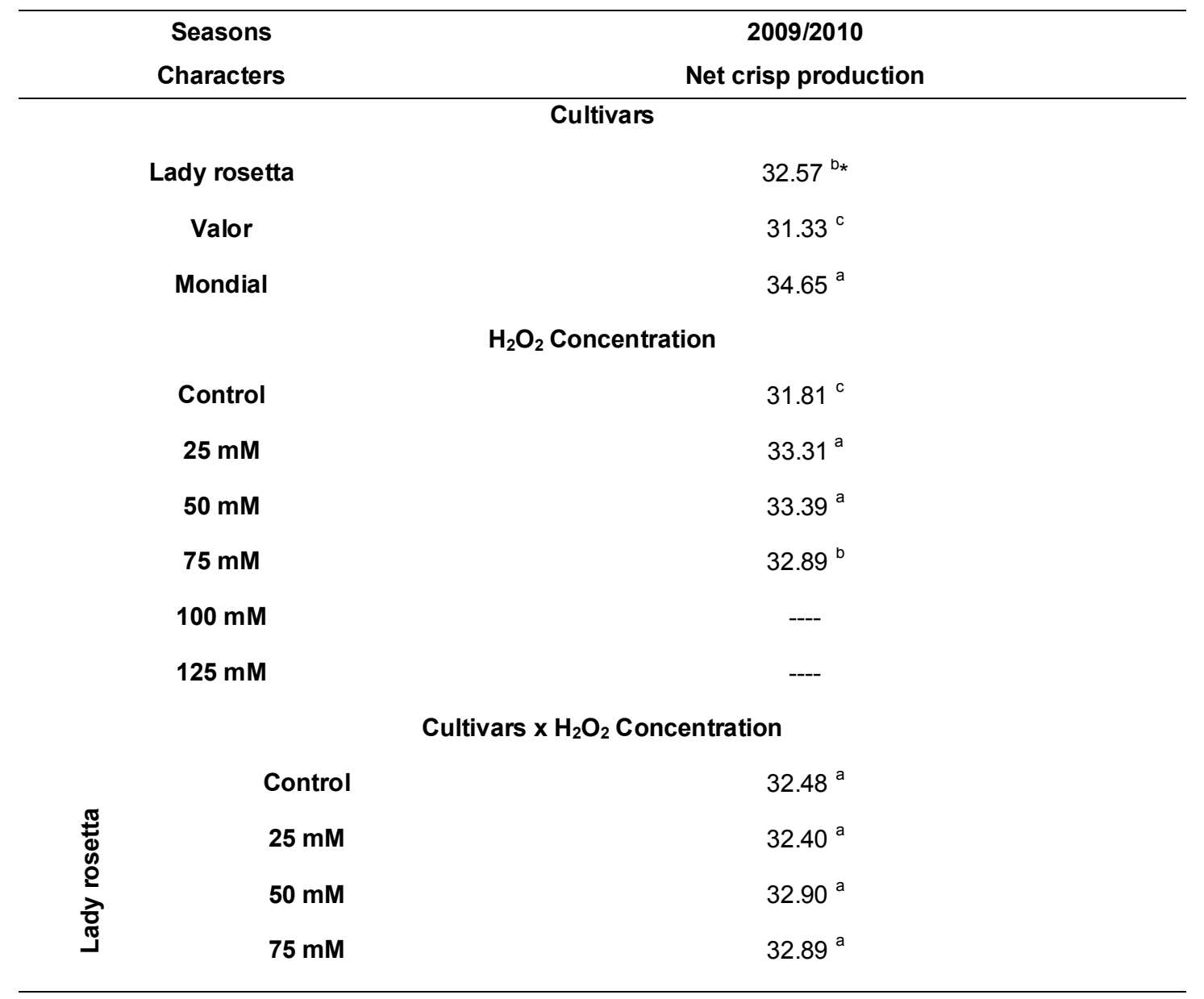




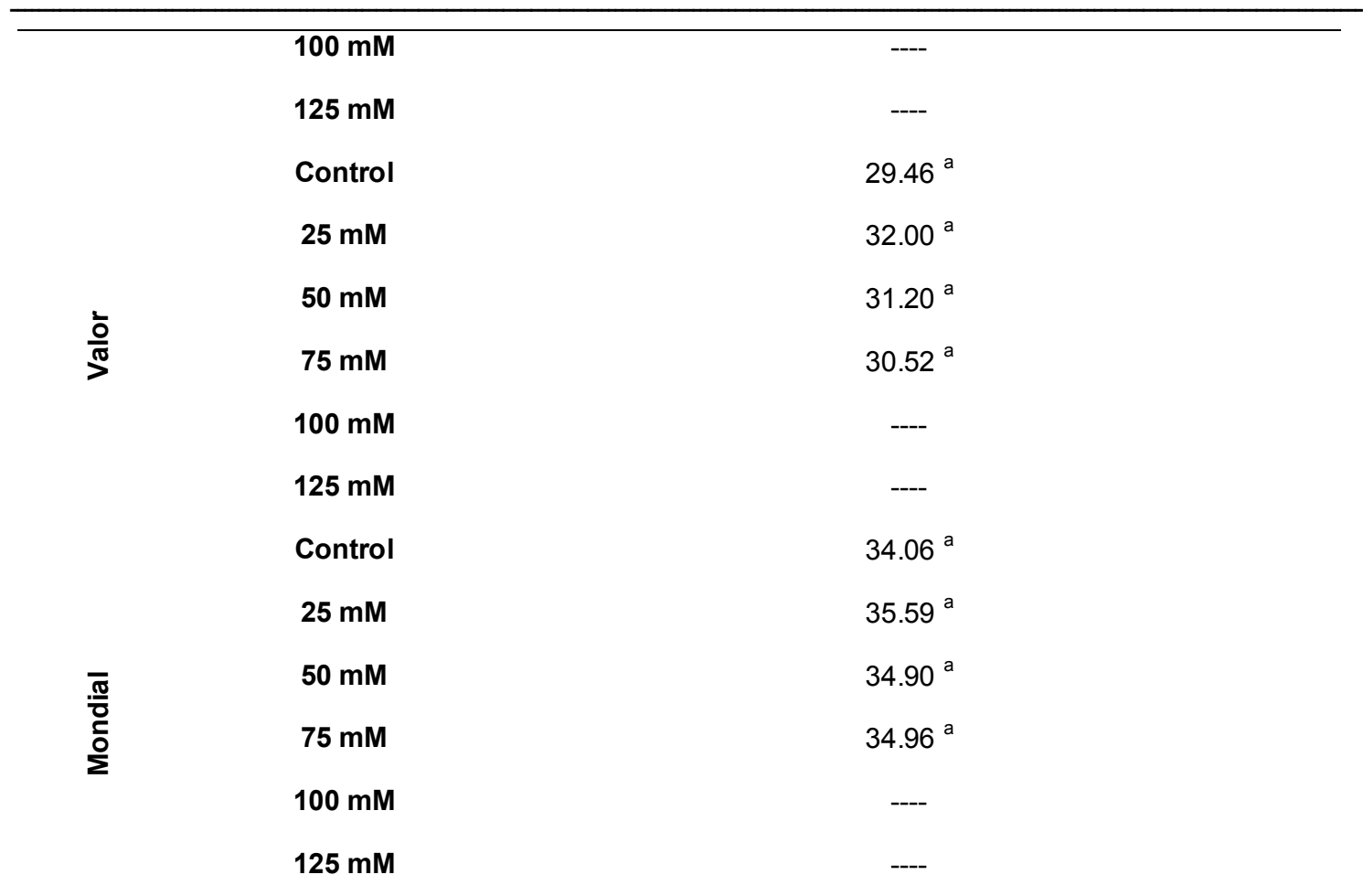

* Values with an alphabetical letter, in a comparable group of means, don't differ significantly from one another using Duncan's Multiple Range Test, at 0.05 level of significance.

----, not treated during the first year

\section{Effect of hydrogen peroxide on both tuber parenchyma cells diameter and tuber chipping defects:}

Parenchyma cell diameter $(\mu \mathrm{m})$ of the tubers of "Valor" cultivar was higher significantly than the other two cultivars in the first season (Table 5). In the first second, "Valor" and "Mondial" cvs. parenchyma cells were the significant widest cells than "Lady Rossitta" cv. which ranked the third. In the first season, $\mathrm{H}_{2} \mathrm{O}_{2}$ treatments affected parenchyma cell diameter. The treatment $50 \mathrm{mM}$ possessed the highest value with insignificant different effects with the treatments zero and 75 $\mathrm{mM} \mathrm{H}_{2} \mathrm{O}_{2}$. The lowest value was produced by the treatment $25 \mathrm{mM}$. In the second season, spraying potato plants with 25 or $125 \mathrm{mM}$ of $\mathrm{H}_{2} \mathrm{O}_{2}$ increased the diameter of parenchyma cells. The treatment $100 \mathrm{mM}$ ranked the second followed with both the treatments 50 and $75 \mathrm{mM}$, while the unsprayed plants treatment produced the lowest value for parenchyma cell diameter. Moussa et al. (2012) reported that parenchyma cells diameter was affected with $\mathrm{H}_{2} \mathrm{O}_{2}$ concentrations. The ratio of increasing in tuber parenchyma cell diameter reached $9.34 \%$ as compared with none treated plants. It is known that starch is mainly stored in cells located parenchyma cells in tubers and thus increasing the diameter of parenchyma cells lead to an increasing in starch content of tubers and these tubers has a positive 
impact on increasing the proportion of tubers dry matter. This result is in harmony with that obtained by Delgado (2005) who stated that the applying $\mathrm{H}_{2} \mathrm{O}_{2}$ lead to enlarged medullar parenchyma cells. The interaction effect between cultivar and $\mathrm{H}_{2} \mathrm{O}_{2}$ was significant during the two years of this study.

The data of Potato chips defects are tabulated in (Table 6). This character was tested only in the season of 2009/2010. Chips quality is a collection of many characteristics and color is one of the most important traits. In general, yellowish brown (Burton et al., 1992), uniform light golden (Stevenson et al., 1964), and lighter colored (Cunningham and Stevenson, 1963) crisps are preferred. The results showed that the tested cultivars differed significantly for potato chips defects. It appeared that the cultivar "Lady Rossetta" pronounced the lowest defects followed by the cultivar "Mondial" while the cultivar "Valor" gave the highest value for chipping defects. Crisps quality is influenced by both genotypic and environmental factors (Stevenson et al., 1964). The data presented clearly showed that spraying potato plants with hydrogen peroxide treatment had significant effects on the tuber chipping defects. The lowest defects were produced when the plants sprayed with $50 \mathrm{mM} \mathrm{H}_{2} \mathrm{O}_{2}$. There were no significant differences effects between the two treatments 25 and $75 \mathrm{mM} \mathrm{H}_{2} \mathrm{O}_{2}$. The control treatment gave the worst result where this treatment produced highly significant level of tuber chipping defects. This result may be related with the previous obtained results for tuber dry matter, tuber starch content and parenchyma cell diameter where the control treatment gave the lowest level for these traits. This research explained that the best results for the previous mentioned traits were given when the plants were sprayed with 50 or $75 \mathrm{mM}$ of $\mathrm{H}_{2} \mathrm{O}_{2}$. There were no significant interactions effects noticed between the tested cultivars and the hydrogen peroxide treatments.

Table (5): Means values' performances of parenchyma cell diameter of tested potato cultivars during both years of 2009/2010 and 2010/2011

\begin{tabular}{ccc}
\hline $\begin{array}{c}\text { Seasons } \\
\text { Characters }\end{array}$ & $\begin{array}{c}\mathbf{2 0 0 9 / 2 0 1 0} \\
\text { Parenchyma cell diameter }(\boldsymbol{\mu m})\end{array}$ & $\begin{array}{c}\mathbf{2 0 1 0 / 2 0 1 1} \\
\text { Cultivars }\end{array}$ \\
\hline Lady rosetta & \multicolumn{2}{c}{ Parenchyma cell diameter $(\boldsymbol{\mu m})$} \\
Valor & $208.3^{\mathrm{b} *}$ & $186.9^{\mathrm{bc}}$ \\
Mondial & $234.4^{\mathrm{a}}$ & $217.1^{\mathrm{a}}$ \\
& $216.2^{\mathrm{b}}$ & $220.9^{\mathrm{a}}$ \\
Control & $\mathbf{H}_{2} \mathrm{O}_{2}$ Concentration & \\
$\mathbf{2 5} \mathbf{~ m M}$ & $219.0^{\mathrm{ab}}$ & $200.3^{\mathrm{a}}$ \\
$\mathbf{5 0 ~} \mathbf{~ m M}$ & $212.1^{\mathrm{b}}$ & $216.6^{\mathrm{a}}$ \\
$\mathbf{7 5 ~} \mathbf{~ m M}$ & $225.9^{\mathrm{a}}$ & $202.1^{\mathrm{cd}}$ \\
& $221.4^{\mathrm{ab}}$ & $205.4^{\mathrm{c}}$ \\
\hline
\end{tabular}

Vol. 19 (1), 2014 
J. Adv. Agric. Res. (Fac. Agric. Saba Basha)

\begin{tabular}{|c|c|c|c|}
\hline & $00 \mathrm{mM}$ & ---- & $209.5^{b}$ \\
\hline & $25 \mathrm{mM}$ & --- & $215.9^{a}$ \\
\hline & & Cultivars & \\
\hline & Control & $192.5^{c}$ & $194.9^{\mathrm{bc}}$ \\
\hline & $25 \mathrm{mM}$ & $207.7^{\mathrm{Dc}}$ & $188.8^{c}$ \\
\hline 导 & $50 \mathrm{mM}$ & $220.6^{b c}$ & $176.6^{c}$ \\
\hline$\geq$ & $75 \mathrm{mM}$ & $212.6^{\mathrm{bc}}$ & $184.5^{\circ}$ \\
\hline & $100 \mathrm{mM}$ & --- & $169.8^{c}$ \\
\hline & $125 \mathrm{mM}$ & --- & $194.3^{\mathrm{bc}}$ \\
\hline & Control & $256.0^{a}$ & $199.8^{b c}$ \\
\hline & $25 \mathrm{mM}$ & $223.6^{\mathrm{bc}}$ & $224.2^{a b}$ \\
\hline & $50 \mathrm{mM}$ & $226.7^{\mathrm{D}}$ & $232.8^{\mathrm{ab}}$ \\
\hline$\frac{n}{\pi}$ & $75 \mathrm{mM}$ & $224.3^{b c}$ & $202.2^{\mathrm{bc}}$ \\
\hline & $100 \mathrm{mM}$ & --- & $224.3^{a b}$ \\
\hline & $125 \mathrm{mM}$ & --- & $208.9^{b c}$ \\
\hline & Control & $212.6^{\mathrm{bc}}$ & $212.6^{\circ}$ \\
\hline & $25 \mathrm{mM}$ & $202.2^{c}$ & $233.4^{a b}$ \\
\hline & $50 \mathrm{mM}$ & $223.6^{\mathrm{bc}}$ & $202.8^{\mathrm{DC}}$ \\
\hline రั & $75 \mathrm{mM}$ & $213.8^{b c}$ & $231.0^{a b}$ \\
\hline & $100 \mathrm{mM}$ & --- & $217.5^{a b}$ \\
\hline & $125 \mathrm{mM}$ & --- & $235.8^{a}$ \\
\hline
\end{tabular}

*Values with an alphabetical letter, in a comparable group of means, don't differ significantly from one another using Duncan's Multiple Range Test, at 0.05 level of significance

----, not treated during the first year 
J. Adv. Agric. Res. (Fac. Agric. Saba Basha)

Table (6): Means values' performances of chips defects of tested potato cultivars during winter season of 2009/ 2010

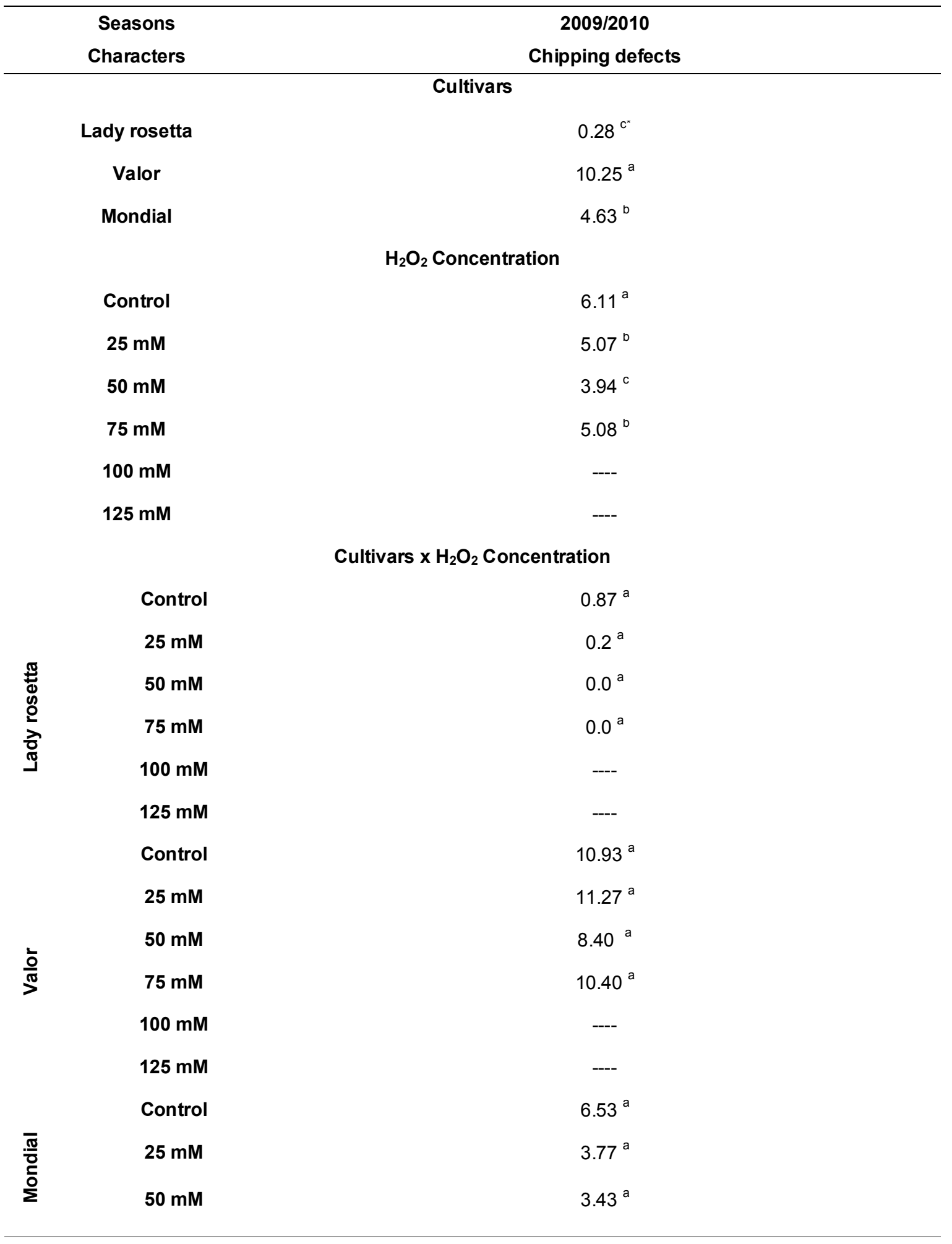




\begin{tabular}{cc}
\hline $75 \mathrm{mM}$ & $4.80^{\mathrm{a}}$ \\
$100 \mathrm{mM}$ & --- \\
$125 \mathrm{mM}$ & ---
\end{tabular}

*Values with an alphabetical letter, in a comparable group of means, don't differ significantly from one another using Duncan's Multiple Range Test, at 0.05 level of significance.

----, not treated during the first year

\section{Conclusions}

It could be concluded that spraying potato plants with hydrogen peroxide positively affected the breadth of parenchyma cell diameter leading to increase tubers starch content, under the conditions of this study. The final results of this research conducted that spraying potato plants with hydrogen peroxide at the rates of 50 or $75 \mathrm{mM}$ starting from 40 days of planting twice a week until maturity stage led to enhancement potato tuber quality which produced the highest values for both tubers starch and dry matter, highest percentage of net crisp with lowest percentage of chipping processing defects.

\section{REFERENCES}

A.O.A.C. (1980). Official Methods of Analysis, Association of Official Agricultural Chemists, Bed., Washington, D.C.P.1018.

Biedermann, B. (2003). How much reducing sugar may potatoes contain to avoid excessive acrylamide formation? Eur. Food Res. Technol. 217: 369-373.

Burton, W.G. A.Van Es, and K.J. Hartmans (1992). The physics and physiology of storage. In: Harris PM (ed) The potato crop, 2nd edn. Chapman and Hall, London, pp 608-727.

Clark, J.P. (2003). Happy birthday, potato chip! And other snack development. Food Technology, 57 (5): 89-92.

Cunningham, C.E, and F.J. Stevenson (1963) Inheritance of factors affecting potato chip color and their association with specific gravity. Am. Potato J., 40(6): 253-265.

Delgado, L., H.A.Z. Mancera, M.E.M. Herrera, M. V. Rivera, F. X. F. Gutierrez and I.M. Scott (2005). Hydrogen Peroxide Increase Potato Tuber and Stem Starch Content, Stem Diameter, and Stem Lignin Content. American Journal of Potato Res. 82: 279-285.

Dinesh, K., R. Ezekiel, B. Singh and I. Ahmed (2005). Conversion Table for specific gravity dry matter and starch content from under water weight of potatoes grown in North India plains. Potato J., 32 (1-2): 79-84.

Dubios, M., K.A. Gulles, J.K. Hamilton, P.A. Rebers and F. Smith (1956). Colourimetric method for determination of sugars and related substances. Analy. Chem., 28: 250-356. 
Duran, M. F. Pedreschi, P. Moyano, and E. Troncoso (2007). Oil partition in pretreated potato slices during frying and cooling. J. Food Eng., 81: 257-265.

Estrada, R.N. (2000). La Biodiversidad en el MejoramientoGentico de la Papa. Centro International de al Papa, Lima, Pero.

FAO. (2010). Data stat Year 2010, Rome, Italy. United Nations Food and Agriculture Organization, Rome.

Frito Lay Company (1999). Potato sending Manual. Operations quality system department. Leicester, United Kingdom.

Gould, W.A. and S.L. Plimpton (1985).Quality evaluation of potato cultivars for processing. Ohio Agric. Res. Dev. Cent. Res. Bull. 1172.

Grodzinsky, A.M. and D.M. Grodzinsky (1973). Short reference in plant physiology. Naukova Domka, Riev., R.U.R. pages, 433-434.

Gurayo, J. and R.G. Moreira (2002). Vacuum frying of potato chips. J. Food Eng., 55: 181-191.

Gutierrez, R. M., M.E.M. Herrera and H.A.L. Delgado (2012). Genous $\mathrm{H}_{2} \mathrm{O}_{2}$ in Phytoplasma-infected potato plants promotes antioxidant activity and tuber production under drought conditions. American Journal of Potato Research, 89: 53-62.

Haase, N.U. (2003). Estimation of dry matter and starch concentration in potatoes by determination of under water weight and near infra red spectroscopy. J. Potato Res., Netherland, 46 (3-4): 117-127.

Kunkel, R.J. Gregory J, and A.M. Binkley (1951). Mechanical separation of potatoes into specific gravity groups shows promise for the potato chip industry. Am. Potato J., 28: 690-696.

Lana, E.P.R.H. Johnson and D.C. Nelson (1970). Variations in specific gravity of potato tubers. Am. Potato J., 47 (1): 9-12.

Moussa, S.A.M., N. Abo El-Fadl and N. Agamy (2012). Role of hydrogen peroxide in improving potato tuber quality. Alex. Sci. Exchange J., 33 (2): 73-88.

Pritchard. M. K. (1993). Relation of sugars to colour of processed potatoes. Univ. Mantoba. Winnipeg. Mantoba R3T 2N2. Mantoba agriculture.

Romero-Romero, M.T. and H. A. López-Delgado (2009). Ameliorative effects of hydrogen peroxide, ascorbate and dehydriascorbate in solanum tuberosum infected by phytoplasma. American Journal of Potato Research, 86: 218-226.

Steel, R.G.D., J.H. Torrie and D.A. Dickie (1997). Principles and procedures of statistics, A Biometric Approach. 3rd Ed. McGraw-Hill, Co. Singapore p. 204-227.

Stevenson, F.J, R.V. Akeley, and C.E. Cunningham (1964). The potato- its genetic and environmental variability. Amer. Potato J., 41(2): 46-53.

Storey, R.MJ., and H.V. Davies (1992). Tuber quality. In: PM Harris (ed), The Potato Crop: The Scientific Basis for Improvement, $2^{\text {ed }}$. Chapman and Hall, London, pp 507-569.

Surmacka, S.A. (2002). Texture is a sensory property. Food Quality Pref., 13: 215225. 
Talburt, W. F. and O. Smith (1987). Potato Processing. (4th ed). Avi Van Nostrand Reinhold Company. New York, p. 796.

$$
\text { الملخص العربى }
$$

تأثير الرش بفوق أكسيد الهيلروجين على صفـات جودة الدرنــات لثلاثة أصناف من البطاطس

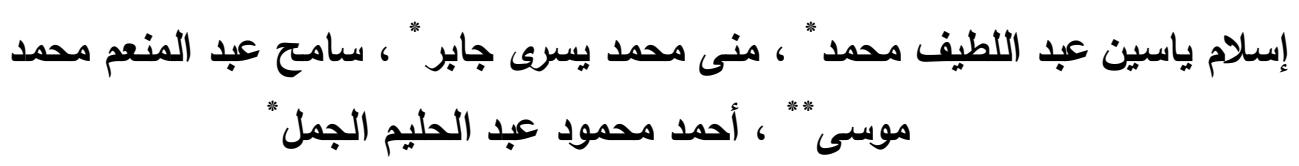

$$
\begin{aligned}
& \text { "كلية الزراعة - سابا باشا - جامعة الاسكندرية" }
\end{aligned}
$$

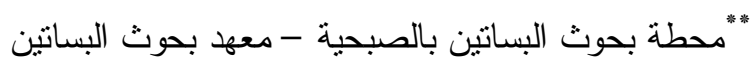

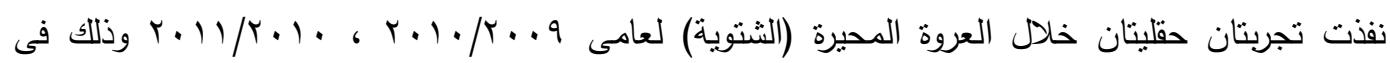

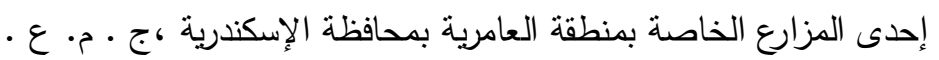

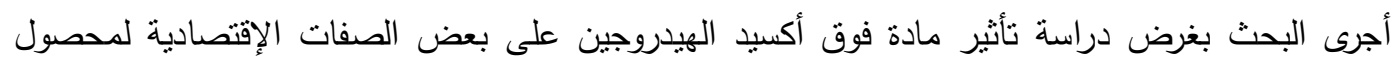
البطاطس وكذلك على صفات جودة الدرنات والمتعلقة بعطلية تصنيع البطاطس ونسبة تصافى المنتج النهائى بأقل نسبة عيوب تصنيعية تؤئز على جودة المنتج. زرعت ثلاثة أصناف من البطاطس وهى ليدى روزيتا ، فالور ، مونديال ـ رشت نباتات البطاطس بتركيزات

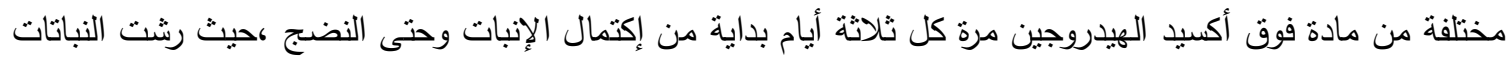

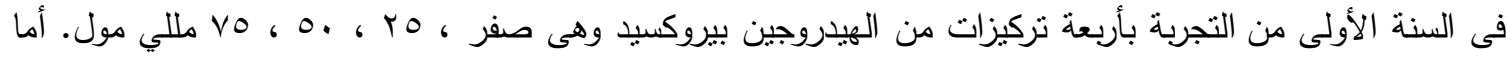

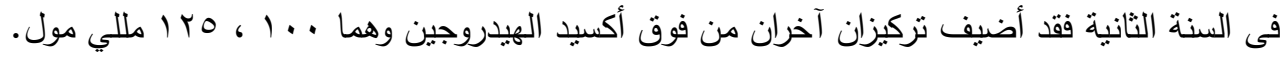
أستخدم فى تطبيق التجربتين خلا السنتين نظام القطع المنشقة فى تصميم القطاعات الكاملة العشوائية، وذللك بثلاث مكررات، حيث وزعت عشوائيا الأصناف على القطع الرئيسية ، بينما معاملات الرش بتركيزات فوق أكسيد

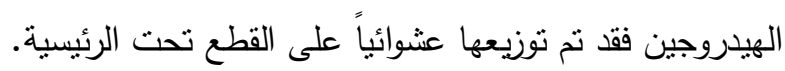
أهم النتائج المتحصل عليها :-

1- إزداد قطر سيقان نباتات البطاطس مع زيادة تركيز الرش بفوق أكسيد الهيدروجين من صفر وحتى نزكيز هب

$$
\text { مللي مول. }
$$

r- لم يكن لتركيزات فوق أكسيد الهيدروجين وحتى نركيز Vo مللي مول أية تأثثر على محصول البطاطس ، أما

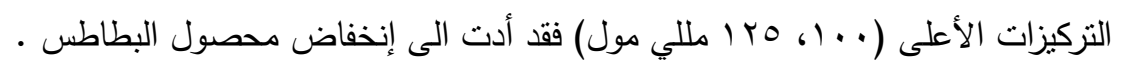


r- كانت هناك زيادة معنوية لنسبة المادة الجافة بالدرنات مع ارتقاع تركيز الرش بفوق أكسيد الهيدروجين الى .0 ،

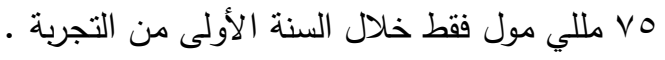

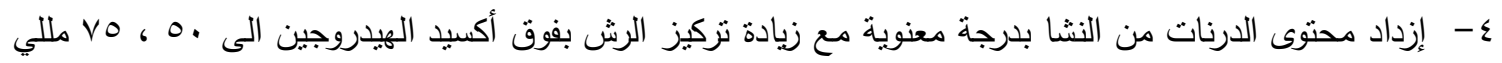

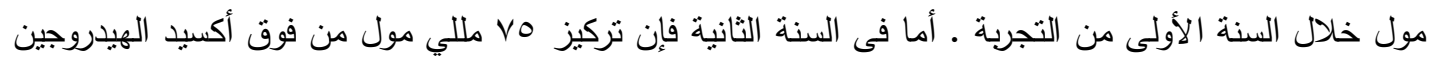
كان له تأير معنوى على زيادة نسبة النشا بالدرنات. ه- - إختلف تأثير الرش بفوق أكسيد الهيدروجين على صفة قطر الخلايا البارانشيمية من سنة الى أخرى حيث أدى الرش بتركيز ه مللي مول فى السنة الأولى من التجربة الى زيادة قطر الخلايا البارانشيمية والمخزنة لحبيبات

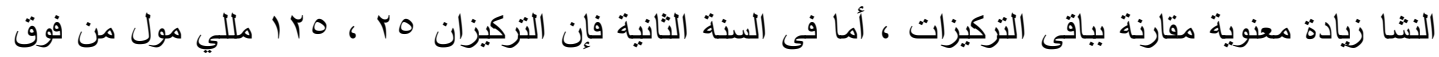

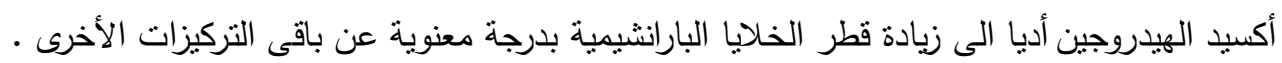

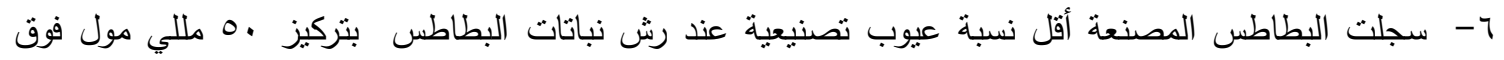

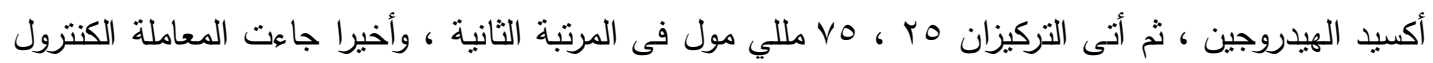

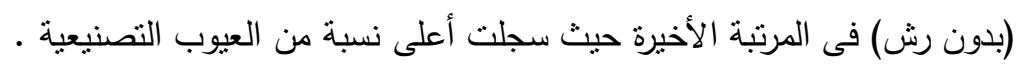

هذا ويوصى البحث بناءا على النتائج السابقة برش نباتات البطاطس بفوق أكسيد الهيدروجين مرنين إسبوعيا

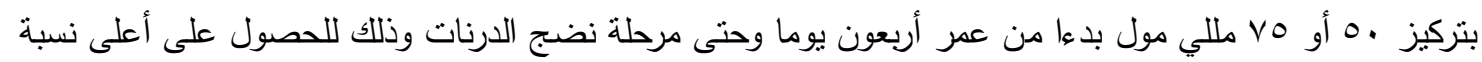

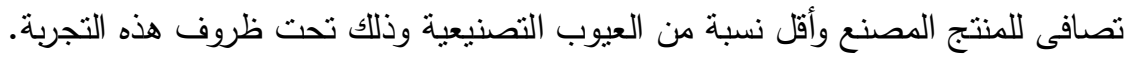


